\title{
Detection of complement fixation by enzyme linked immunosorbant assay (COMPELISA)
}

\author{
PM HINCHLIFFE, L ROBERTSON \\ From the Public Health Laboratory, Meadow St, Preston
}

SUMMARY A method is described by which complement fixation is detected with an enzyme linkeक़क immunosorbant assay (ELISA) technique. The method obviates the need for sensitised sheep red blood cells as an indicator of complement fixation and the titration of complement is not critical $\stackrel{\circ}{=}^{\circ}$ The dose response curve has the advantage of being steep and the test result is readphotometrically. As test serum and complement do not react together serum anticomplementary effects are eliminated. The ELISA complement fixation test (COMPELISA) was more sensitive than the conventional CFT for detecting brucella antibodies.

The complement fixation test (CFT) is widely used for detecting antibodies to many bacterial, viral, and other antigens. A specific amount of complement of known activity is incubated with antigen and a possible source of antibody such as a patient's serum. If an immune reaction takes place some or all of the complement may be fixed on to the antigen-antibody complex. The residual complement is assayed by its ability to haemolyse sensitised sheep red blood cells and the antibody titre can be expressed as that dilution of serum which leaves sufficient complement free to haemolyse $50 \%$ of the red cells.

The ELISA CFT (COMPELISA) estimates the amount of complement fixed directly with a specific peroxidase conjugated goat anti-guinea-pig C3 serum. A similar technique, termed CELISA, was described by Tandon et $\mathrm{al}^{3}$ in the serological investigation of Chagas' disease.

\section{Material and methods}

REAGENTS

\section{Antigens}

These are lipopolysaccharides extracted from freezedried Brucella abortus (Ipswich strain) and $B$ melitensis (Bangalore strain) cells by treatment with ethylene-diaminetetra-acetate (EDTA) at $37^{\circ} \mathrm{C} .{ }^{\prime}$

\section{Complement}

Guinea-pig serum preserved by Richardson's method $^{2}$ and freeze-dried (Don Whitley).

Accepted for publication 28 July 1982
Peroxidase conjugated goat anti-guinea-pig C3 serun This reagent is prepared by Cappel Labs Inc, Cochranville, PA, USA and is supplied by Dynated Laboratories Ltd, Billingshurst, England.

\section{Substrate}

The substrate was prepared by dissolving $40 \mathrm{~m}$ $o$-phenylenediamine in $100 \mathrm{ml}$ phosphate-citrate buffer, pH 5, and adding, immediately before use, $\mu \mathrm{l}$ of $30 \mathrm{vol} \mathrm{H}_{2} \mathrm{O}_{2}$.

\section{Sera}

Human sera were diluted $1 / 40$ in phosphate-buffere saline containing $0.05 \%$ Tween 20 (PBST) and inactivated by heating at $56^{\circ} \mathrm{C}$ for $30 \mathrm{~min}$.

\section{Solid phase support}

LINBRO flat-bottomed 96 well microtitration plates (Flow Labs 76-381-04).

METHOD

The COMPELISA utilises the ELISA technique described by Voller et al. ${ }^{4}$ The antigens were dilutad in carbonate-bicarbonate coating buffer, $\mathrm{pH} 9 \cdot 6$, and distributed in $200 \mu \mathrm{l}$ volumes into the wells of the plate which was then kept at $4^{\circ} \mathrm{C}$ overnight. The plate was washed three times in PBST with three minutes contact between washes.

The test sera were dispensed into the wells in 200 制 volumes. The plate was covered and incubated fof one hour at room temperature in a moist chamber. to was then washed as before and $200 \mu \mathrm{l}$ of guine pig complement, suitably diluted in PBST, wers distributed into the wells. The plate was incubated room temperature for one hour and then wash 
three times. Anti-guinea-pig C3 conjugate in $200 \mu \mathrm{l}$ volumes was added to each well and the plate incubated at room temperature for $2 \mathrm{~h}$. After washing, substrate was added to each well in $200 \mu \mathrm{l}$ volumes and the plate incubated at room temperature in the dark for $30 \mathrm{~min}$. Finally $50 \mu \mathrm{l}$ of $2 \mathrm{M} \mathrm{H}_{2} \mathrm{SO}_{4}$ was added to each well and the intensity of the resultant colour was measured in a Dynatech MiniELISA Reader at a wavelength of $490 \mathrm{~nm}$.

\section{Conjugate concentration (Table 1)}

A chessboard titration was set up as follows. Preserved guinea-pig serum was diluted 1/8 with distilled water to obtain a $1 / 10$ isotonic solution. Further tenfold dilutions from $1 / 10^{2}$ to $1 / 10^{5}$ were prepared in coating buffer and a row of eight wells was coated with each dilution. As negative controls two further rows were added, one exposed to buffer only and the other coated with a 1/40 dilution of human serum. After washing, the coated wells were allowed to react with $200 \mu \mathrm{l}$ volumes of twofold dilutions of conjugate, $1 / 500$ to $1 / 32000$, and the ELISA completed as described above.

\section{Antigen concentration}

The optimum antigen concentration was determined with a chessboard titration against positive serum followed by the addition of excess complement and optimally diluted conjugate. The dilution of antigen found to give maximum absorbance with the highest dilution of serum was considered to be the optimum.

\section{Complement concentration}

The optimum concentration of complement was determined with a chessboard titration in which antigen and conjugate were used at their optimum concentrations. The solid phase antigen was exposed to dilutions of positive and negative human serum and, after washing, varying dilutions of complement were added. The weakest concentration of complement giving maximum absorbance with the positive serum and showing no reaction with the negative serum was chosen as the optimum concentration. In practice, although wasteful, an excess of complement can be added and this does not significantly affect the absorbance.
Table 2 Comparison of COMPELISA absorbances of two specimens at different times and temperatures of incubation

\begin{tabular}{|c|c|c|c|c|}
\hline \multirow[t]{2}{*}{ Reciprocal serum dilution } & \multicolumn{2}{|c|}{ Serum $A$} & \multicolumn{2}{|c|}{ Serum B } \\
\hline & $\begin{array}{l}4^{\circ} \mathrm{C} \text { for } \\
18 \mathrm{~h}\end{array}$ & $\begin{array}{l}R T \text { for } \\
I h\end{array}$ & $\begin{array}{l}4^{\circ} \mathrm{C} \text { for } \\
18 \mathrm{~h}\end{array}$ & $\begin{array}{l}R T \text { for } \\
l h\end{array}$ \\
\hline 40 & 174 & 194 & 196 & 196 \\
\hline 80 & 98 & 112 & 125 & 190 \\
\hline 160 & 30 & 10 & 27 & 35 \\
\hline 320 & 8 & 0 & 5 & 3 \\
\hline 640 & 0 & 0 & 0 & 0 \\
\hline
\end{tabular}

$\mathrm{RT}=$ room temperature

Time and temperature of incubation (Table 2)

Two combinations of time and temperature of incubation were compared by titrating two positive sera at $4^{\circ} \mathrm{C}$ for $18 \mathrm{~h}$ and at room temperature for one hour.

\section{Controls}

All COMPELISA tests must include a negative control for each serum in which complement is replaced with PBST. Each batch of tests should include a control prepared from pooled negative serum and positive serum controls should be serially diluted over a suitable range with $20 \%$ differences between dilutions. Sera should initially be screened at a dilution of $1 / 40$ in duplicate and if the absorbance readings differ from their mean by more than $10 \%$ of the mean the test should be repeated assuming that at least one of the readings is in the positive range.

\section{Results}

The results of the antigen and complement titrations showed their optimum concentrations to be $1 / 200$ and $1 / 100$ respectively. Table 1 contains the results of the conjugate titration. The optimum dilution was taken as $1 / 1000$ because the lower dilution of $1 / 500$, while giving slightly higher absorbances, also showed a threefold increase in absorbance with the human serum negative control. It is important that the anti-guinea-pig $\mathrm{C} 3$ conjugate should have minimum reaction with human immunoglobulin, the con-

Table 1 Absorbances of anti-guinea-pig C3 conjugate reactions with guinea-pig serum adsorbed on to plastic microtitration plate

\begin{tabular}{|c|c|c|c|c|c|c|c|c|}
\hline \multirow[t]{2}{*}{ Guinea-pig serum. Reciprocal dilutions } & \multicolumn{8}{|c|}{ Anti-guinea-pig C3 conjugate: reciprocal dilutions } \\
\hline & 500 & 1000 & 2000 & 4000 & 8000 & 16000 & 32000 & Control \\
\hline $\begin{array}{l}10^{2} \\
10^{3} \\
10^{4} \\
10^{5} \\
\text { Neg control } \\
\text { Human serum control }\end{array}$ & $\begin{array}{r}101 \\
145 \\
112 \\
35 \\
14 \\
66\end{array}$ & $\begin{array}{r}92 \\
120 \\
101 \\
18 \\
3 \\
23\end{array}$ & $\begin{array}{r}66 \\
107 \\
86 \\
14 \\
6 \\
23\end{array}$ & $\begin{array}{r}62 \\
86 \\
68 \\
15 \\
2 \\
18\end{array}$ & $\begin{array}{r}49 \\
57 \\
50 \\
9 \\
1 \\
17\end{array}$ & $\begin{array}{r}35 \\
44 \\
37 \\
8 \\
3 \\
11\end{array}$ & $\begin{array}{r}23 \\
22 \\
19 \\
4 \\
0 \\
6\end{array}$ & $\begin{array}{l}0 \\
0 \\
0 \\
0 \\
0 \\
0\end{array}$ \\
\hline
\end{tabular}


centration of which, in this negative control, is much higher than would be encountered in a routine positive test where only the human antibrucella immunoglobulin is retained.

Table 2 contains the results of a comparison between two time/temperature combinations. It can be seen that with both sera the differences are small, with higher absorbances at low serum dilution resulting from incubation at room temperature for one hour rather than at $4^{\circ} \mathrm{C}$ overnight.

Table 3 compares the CFT results of 20 sera with their COMPELISA absorbances. A high correlation is evident though this can be seen more clearly in Table 4. An interesting feature is the large reduction in absorbance which often results from a twofold dilution of serum.

Table 4 shows the distribution of the results of 130 serum specimens, including those contained in Table 3 , into specified categories of COMPELISA and
Table 4 Combined distribution of COMPELISA results and CFT results of 130 human sera tested against brucella antigen

\begin{tabular}{|c|c|c|c|c|}
\hline \multirow[t]{2}{*}{ Reciprocal CFT titre } & \multicolumn{4}{|c|}{ COMPELISA absorptions } \\
\hline & $0-19$ & $20-39$ & $40-100$ & $\geqslant 101$ \\
\hline$<10$ & 79 & 1 & 1 & \\
\hline 10 & 10 & 2 & 4 & 1 \\
\hline 20 & & & 3 & 6 \\
\hline 4) & & & 1 & 2 \\
\hline 80 & & & & 8 \\
\hline 160 & & & & 6 \\
\hline 320 & & & & 3 \\
\hline 640 & & & & 3 \\
\hline
\end{tabular}

CFT. Of those 81 sera which had a CFT titre $<1 / 10$ one had a COMPELISA absorbance greater than $20 \omega$ and one had an absorbance $>40$. Seventeen sera had ${ }^{-}$ a CFT titre of $1 / 10$. Four of these had absorbances of 40 to 100 and one had an absorbance of $>100$. Of theo 12 sera which had CFT titres of $1 / 20$ or $1 / 40$, four had

Table 3 Comparison of conventional CFT and COMPELISA: results of 20 sera

\begin{tabular}{|c|c|c|c|c|c|c|c|c|}
\hline \multirow[t]{2}{*}{ Specimen No } & \multirow[t]{2}{*}{ Antigen } & \multirow[t]{2}{*}{$\begin{array}{l}\text { CFT titre } \\
\text { (recip) }\end{array}$} & \multicolumn{5}{|c|}{$\begin{array}{l}\text { COMPELISA } \\
\text { Absorbance at a dilution of: }\end{array}$} & \multirow{2}{*}{$\begin{array}{l}\vec{\Sigma} \\
\vec{\omega} \\
\infty \\
\omega\end{array}$} \\
\hline & & & $1 / 40$ & $1 / 80$ & $1 / 160$ & $1 / 320$ & $1 / 640$ & \\
\hline \multirow{2}{*}{1} & $\mathrm{Ab}$ & 320 & $>200$ & $>200$ & $>200$ & 199 & 65 & $\square$ \\
\hline & Mel & 320 & $>200$ & $>200$ & $>200$ & 145 & 44 & c \\
\hline \multirow{2}{*}{2} & $\mathrm{Ab}$ & 10 & 0 & 0 & 0 & 0 & 0 & $\leq$ \\
\hline & $\mathrm{Mel}$ & $<10$ & 1 & 0 & 0 & 1 & 0 & $\bar{o}$ \\
\hline \multirow[t]{2}{*}{3} & $\mathrm{Ab}$ & 10 & 1 & 0 & () & 0 & 0 & 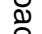 \\
\hline & Mel & $<10$ & 3 & 1 & 1 & 0 & 0 & 응 \\
\hline 4 & $\mathrm{Ab}$ & $<10$ & 0 & 0 & 0 & 0 & 0 & 2 \\
\hline \multirow{2}{*}{5} & $\begin{array}{l}\mathrm{Mel} \\
\mathrm{Ab}\end{array}$ & $\begin{array}{l}<10 \\
<10\end{array}$ & $\begin{array}{l}0 \\
18\end{array}$ & $\begin{array}{l}0 \\
4\end{array}$ & 1 & $\begin{array}{l}0 \\
2\end{array}$ & $\begin{array}{l}0 \\
0\end{array}$ & th \\
\hline & $\mathrm{Mel}$ & $<10$ & $\begin{array}{r}18 \\
9\end{array}$ & $\frac{4}{2}$ & 1 & 0 & $\begin{array}{l}0 \\
1\end{array}$ & 욱 \\
\hline \multirow[t]{2}{*}{6} & $\mathrm{Ab}$ & $<10$ & 11 & 4 & 1 & 0 & 0 & $\bar{J}$ \\
\hline & Mel & $<10$ & 7 & 3 & 2 & 0 & 0 & $\overrightarrow{2}$ \\
\hline \multirow[t]{2}{*}{7} & $\mathrm{Ab}$ & 80 & 165 & 95 & 26 & 13 & 1 & 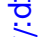 \\
\hline & Mel & 10 & 13 & 3 & 1 & 1 & 0 & 3 \\
\hline \multirow{2}{*}{8} & $\mathrm{Ab}$ & 10 & 17 & 6 & 3 & 0 & 0 & t \\
\hline & Mel & 10 & 10 & 4 & 2 & 1 & 1 & \\
\hline \multirow{2}{*}{9} & $\mathrm{Ab}$ & $<10$ & 4 & 1 & () & 0 & 0 & 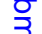 \\
\hline & Mel & $<10$ & 4 & 1 & 1 & 0 & 0 & 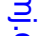 \\
\hline \multirow{2}{*}{10} & $\mathrm{Ab}$ & 40 & 97 & 37 & 16 & 6 & 1 & $\dot{~}$ \\
\hline & Mel & 20 & 81 & 26 & 7 & 2 & 2 & $\cong$ \\
\hline \multirow{2}{*}{11} & $\mathrm{Ab}$ & $<10$ & 10 & 2 & 3 & 0 & 0 & 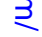 \\
\hline & Mel & $<10$ & 10 & 4 & 4 & 1 & 1 & c \\
\hline \multirow{2}{*}{12} & $\mathrm{Ab}$ & 160 & 102 & 35 & 5 & 7 & 1 & $=$ \\
\hline & Mel & 10 & 10 & 4 & 2 & 1 & 0 & \\
\hline \multirow{2}{*}{13} & $\mathrm{Ab}$ & 320 & $>200$ & $>200$ & $>200$ & 192 & 68 & \\
\hline & Mel & 160 & $>200$ & $>200$ & $>200$ & 156 & 57 & \\
\hline \multirow{2}{*}{14} & $\mathrm{Ab}$ & 80 & $>200$ & 155 & 47 & 8 & 1 & 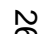 \\
\hline & Mel & 80 & 17 & 4 & 0 & 0 & 0 & 7 \\
\hline \multirow{2}{*}{15} & $\mathrm{Ab}$ & 80 & $>200$ & 128 & 22 & 1 & 0 & 1 \\
\hline & Mel & 10 & 6 & 1 & 0 & 0 & 0 & c \\
\hline \multirow{2}{*}{16} & $\mathrm{Ab}$ & 80 & $>200$ & 182 & 42 & 5 & 1 & S \\
\hline & Mel & 10 & 29 & 6 & 0 & 0 & 1 & S \\
\hline \multirow[t]{2}{*}{17} & $\mathrm{Ab}$ & 160 & $>200$ & 175 & 17 & 2 & 0 & S \\
\hline & Mel & 640 & $>200$ & $>200$ & $>200$ & 199 & 50 & 0 \\
\hline \multirow{2}{*}{18} & $\mathrm{Ab}$ & 80 & $>200$ & 55 & 6 & 1 & 0 & $\frac{\pi}{0}$ \\
\hline & Mel & 160 & $>200$ & $>200$ & 114 & 6 & 3 & 8 \\
\hline \multirow{2}{*}{19} & $\mathrm{Ab}$ & 80 & 154 & 22 & 2 & 0 & 0 & ? \\
\hline & $\mathrm{Mel}$ & 80 & $>200$ & 135 & 16 & 0 & 1 & . \\
\hline 20 & $\mathrm{Ab}$ & 2560 & 198 & 198 & 197 & 188 & 117 & \\
\hline & Mel & 640 & $>200$ & $>200$ & 190 & 180 & 62 & \\
\hline
\end{tabular}




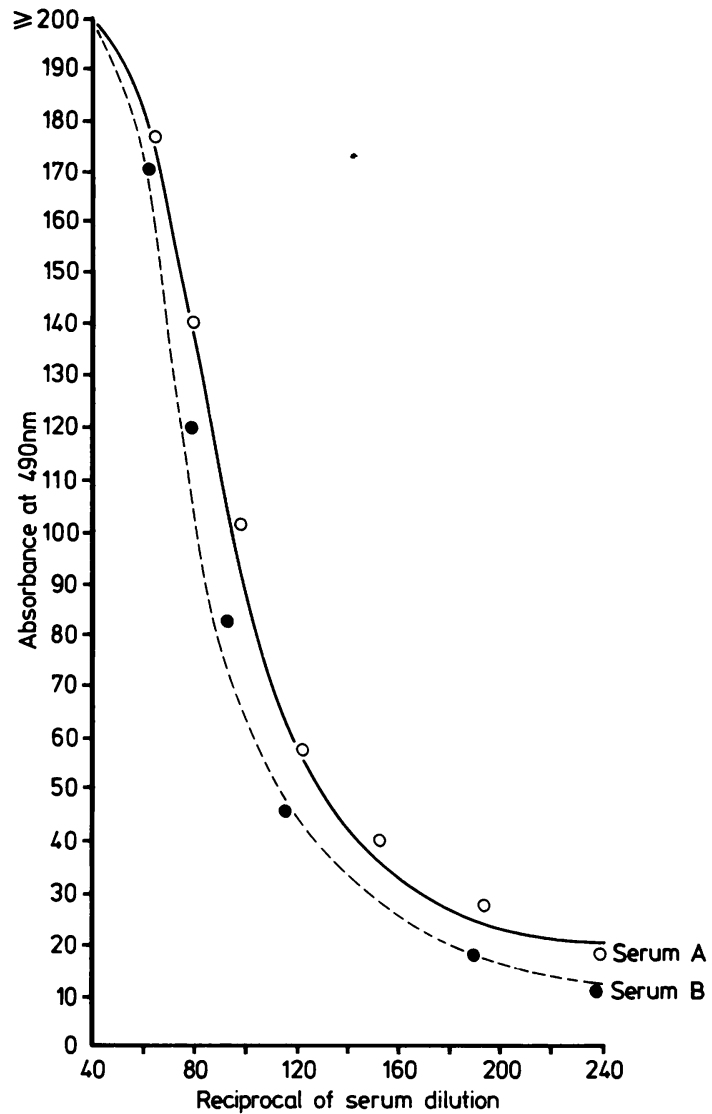

Graph of COMPELISA absorbance of serum reaction with brucella antigen

absorbances of 40 to 100 and eight had absorbances of $>100$.

All 20 sera which had CFT titres $>1 / 80$ had COMPELISA absorbances $>100$.

The Figure shows two graphs generated by plotting the COMPELISA absorbances of serum dilutions prepared at $20 \%$ intervals. Features of interest are the near linearity of the graphs between absorbances of 50 and 150 (correlation coefficient $=0.97$ ), and the steepness of the graphs in this region, resulting in large differences in absorbance for small differences in serum dilution.

\section{Discussion}

The COMPELISA has several advantages over the conventional CFT. It does not require sheep red blood cells and the titration of complement is not so critical. Comparative tests showed there to be no advantage in incorporating veronal in the complement diluent. The assay can take advantage of the automation already designed for ELISA and the end-point of the test, a colour reaction, can be quantified photometrically.

As the results in Table 2 show, the time/ temperature combinations of 18 hours at $4^{\circ} \mathrm{C}$ and one hour at room temperature gave similar results and the choice is one of convenience.

Whatever the animal species of the serum being examined the COMPELISA requires only the antiguinea-pig C3 conjugate. This also applies when human sera are being examined together with control sera which have been raised in, for example, rabbits. In contrast the ELISA needs different and expensive species-specific antiserum conjugates according to the source of the antibody to be detected.

In trying to interpret the shape of the graphs in the Figure it is necessary to take into account the fact that the response of the photometer is not linear over the entire absorbance range of 0-200. However, an absorbance of 100 appears to lie in the centre of the most sensitive linear region of response and if results are to be reported as titres the appropriate dilution would be that which, by interpolation, gives this absorbance.

Screening test sera at a dilution of $1 / 40$ would enable those specimens with results which fall in the normal range, as determined by each laboratory, to be excluded from further investigation. Sera giving a positive result may require further dilution.

In the COMPELISA patient's serum and complement are not combined in the presence of antigen as in the CFT and therefore serum anticomplementary effects are eliminated.

The overall results as shown in Table 4 indicate that the COMPELISA is the more sensitive of the two tests for while none of the sera which had COMPELISA absorbances of $0-19$ had CFT titres greater than $1 / 10,41 \%(7 / 17)$ of those sera which had CFT titres of $1 / 10$ gave COMPELISA absorbances greater than 19 .

\section{References}

' Leive L, Shovlin VK, Mergenhagan SE. Physical, chemical and immunological properties of lipopolysaccharide released from $E$ coli by ethylenediaminetetra-acetate. $J$ Biol Chem 1968;243:6384-91.

2 Richardson GM. The preservation of liquid complement serum. Lancet 1941;ii:696.

${ }^{3}$ Tandon A, Zahner H, Lammler G. CELISA (Complement Enzyme Linked Immunosorbant Assay) a new method for the estimation of complement fixing antibodies: its use for Chagas disease. Tropenmed Parasitol 1979;30:189-93.

4 Voller A, Bidwell DE, Bartlet A. The enzyme linked immunosorbant assay (ELISA). Micro Systems Ltd, Summerfield House, Vale, Guernsey, 1979.

Requests for reprints to: Mr P Hinchliffe, Pathological Laboratory, Sharoe Green Hospital, Fulwood, Preston PR2 4DU, England. 